\title{
IDENTYFIKACJA PROCESU ZAOPATRZENIA W SYSTEMIE LOGISTYCZNYM PRZEDSIĘBIORSTWA HANDLU DETALICZNEGO WIELKOPOWIERZCHNIOWEGO
}

\begin{abstract}
Analiza literatury przedmiotu wskazuje na brak szczegółowych opracowań odnoszących się do pojęcia i struktury systemu logistycznego przedsiębiorstwa handlu detalicznego wielkopowierzchniowego oraz charakterystyki realizowanych tam procesów. Prezentowana treść ma charakter ogólny, nie uwzględnia specyfiki podmiotowej czy przedmiotowej handlu detalicznego. Celem artykułu jest uzupełnienie powstałej luki. Podejmowane działania prowadzą do identyfikacji i charakterystyki procesu zaopatrzenia w systemach logistycznych przedsiębiorstwa handlu detalicznego wielkopowierzchniowego poprzez wskazanie jego celu, etapów i zadań, stosowanych dokumentów oraz osób odpowiedzialnych i wykonawców. Jako metodę badawczą zastosowano analizę literatury przedmiotu oraz obserwację bezpośrednią. Realizacja badania odbywa się w dwóch etapach. Etap pierwszy to identyfikacja i charakterystyka systemu logistycznego badanego przedsiębiorstwa w ujęciu podmiotowym, rzeczowym oraz czynnościowym. Efektem podejmowanych działań jest wyznaczenie i omówienie struktury organizacyjnej badanego przedsiębiorstwa oraz opracowanie planu zagospodarowania jego podstawowej powierzchni - hali sprzedaży i magazynu. Dodatkowo w ramach tego etapu zawarta jest charakterystyka środków pracy przez identyfikację przedmiotu obsługi oraz stosowanych urządzeń technicznych. W końcowej części wskazano główne procesy logistyczne. Etap drugi to identyfikacja i charakterystyka procesu zaopatrzenia w badanym systemie. Uwzględniając powszechnie stasowany podział procesu zaopatrzenia na dwie fazy: przygotowania i realizacji, oraz strukturę podmiotową, rzeczową i czynnościową systemu logistycznego, w ramach każdej z faz wyznaczono etapy i zadania. Natomiast $w$ ramach poszczególnych zadań wskazano osoby odpowiedzialne za ich realizację i wykonawców oraz dodatkowo stosowane dokumenty wejścia i wyjścia. Wynikiem końcowym rozważań jest budowa i opracowanie schematu realizacji procesu zaopatrzenia.
\end{abstract}

Słowa kluczowe: logistyka, dystrybucja, zaopatrzenie, zamówienie, dostawca, zapas

\section{WPROWADZENIE}

W literaturze przedmiotu pojęcie dystrybucja oznacza ogniwo pośrednie między produkcją i konsumpcją, a jej głównym celem jest wypełnienie luki czasowej, przestrzennej, ilościowej, asortymentowej czy informacyjnej dzielącej te obszary². Jako podstawowe części składowe dystrybucji należy wskazać kanał dystrybucji i fizyczny przepływ towarów. Kanały dystrybucji to zbiór wzajemnie powiązanych podmiotów, które współdziałają w różnych płaszczyznach w celu dostarczania określonych dóbr lub usług odbiorcom do

\footnotetext{
${ }^{1}$ Dr Zdzisław Jedynak, Wydział Zarządzania, Politechnika Rzeszowska, al. Powstańców Warszawy 12, 35-959 Rzeszów, tel.: 698400 287, e-mail: zjedynak@ prz.edu.pl

${ }^{2}$ M. Christopher, Strategia zarządzania dystrybucja, Agencja Wydawnicza Placet, Warszawa 1996.
} 
konsumpcji czy przetworzenia ${ }^{3}$. Jednym z podmiotów są przedsiębiorstwa handlu detalicznego. Pojęcie handel detaliczny oznacza ogół czynności związanych ze sprzedażą towarów czy usług określonym odbiorcom najczęściej na ich własny i niebiznesowy użytek $^{4}$. Należy podkreślić, że działalność ta prowadzona jest w różnych formach. Ważną grupę stanowią przedsiębiorstwa handlu detalicznego wielkopowierzchniowego (PHD/W), tzw. hipermarkety. Natomiast fizyczny przepływ towarów to proces, w którego ramach wykonywane są określone funkcje logistyczne, a efektem końcowym jest doprowadzenie produktu do końcowego odbiorcy. Na poziomie przedsiębiorstwa proces ten dzieli się na dwie fazy: zaopatrzenia i dystrybucji. Pierwsza faza obejmuje czynności, których zakres wychodzi poza granicę przedsiębiorstwa, a celem podejmowanych działań jest zapewnienie przedsiębiorstwu dostępu do określonych dóbr i usług w danym czasie $\mathrm{i}$ miejscu, w odpowiedniej ilości i jakości oraz po akceptowanych cenach i kosztach obsługi logistycznej, które są niezbędne do utrzymania czy poszerzenia prowadzonej działalności.

Analiza literatury przedmiotu wskazuje na brak szczegółowych opracowań odnoszących się do pojęcia i struktury systemu logistycznego PHD/W oraz charakterystyki realizowanych tam procesów, w tym zaopatrzenia. Prezentowana treść ma charakter ogólny, nie uwzględnia specyfiki podmiotowej czy przedmiotowej handlu detalicznego. Celem artykułu jest uzupełnienie powstałej luki. Podejmowane działania prowadzą do identyfikacji i charakterystyki procesu zaopatrzenia w systemach logistycznych przedsiębiorstwa handlu detalicznego wielkopowierzchniowego (PHD/W) poprzez wskazanie jego celu, etapów i zadań, stosowanych dokumentów oraz osób odpowiedzialnych i wykonawców. Etapy jego realizacji obejmują charakterystykę systemu logistycznego w ujęciu podmiotowym, przedmiotowym i czynnościowym oraz identyfikację i charakterystykę procesu zaopatrzenia. Jako metodę badawczą zastosowano analizę literatury przedmiotu oraz obserwację bezpośrednią.

\section{SYSTEM LOGISTYCZNY PRZEDSIĘBIORSTWA - POJĘCIE I ZAKRES}

Na potrzeby realizacji przyjętego celu artykułu badany system będzie prezentowany w trzech ujęciach: podmiotowym, rzeczowym i czynnościowym. W ujęciu podmiotowym system logistyczny PHD/W to jeden z wydzielonych podsystemów przedsiębiorstwa. Jest to systemem wewnątrzorganizacyjnym, który składa się z sieci powiązanych i współpracujących w różnych obszarach działów funkcjonalnych i zadaniowych oraz pracowników. Jego struktura obejmuje: podsystem przyjęcia i wydania towaru, podsystem handlowy oraz podsystem logistycznej obsługi klienta. W ramach każdego podsystemu należy wskazać cztery podstawowe grupy pracowników: kadrę zarządczą i kierowniczą (osoby decyzyjne i wspierające), pracowników podstawowych (wykonawczych) oraz pracowników pomocniczych (specjalista ds. BHP, pracownik techniczny, ochrony czy sprzątający). Strukturę organizacyjną PHD/W przedstawiono na rysunku 1.

\footnotetext{
${ }^{3}$ Logistyka dystrybucji, red. K. Rutkowski, Difin, Warszawa 2000.

${ }^{4}$ J.G. Armstrong, Ph. Kotler, Marketing - Wprowadzenie, Oficyna Wydawnicza Wolters Kluwer business, Warszaw 2012.
} 
Rys. 1. Struktura organizacyjna przedsiębiorstwa handlu detalicznego wielkopowierzchniowego (PHD/W)

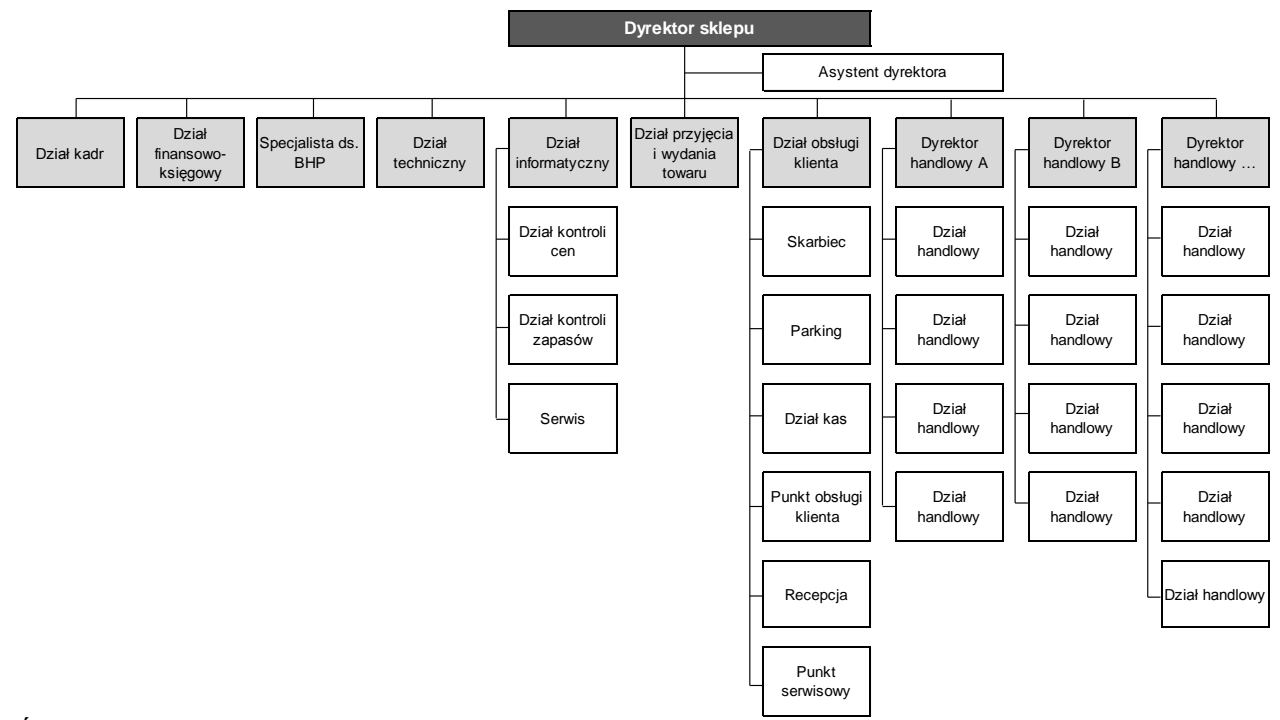

Źródło: opracowanie własne.

W ujęciu rzeczowym system logistyczny w PHD/W jest definiowany na podstawie przedmiotów pracy i środków pracy. Przedmiotem jest towar, który stanowi ofertę handlową przedsiębiorstwa. W hipermarketach spożywczych można wyróżnić trzy podstawowe grupy produktów: suchej żywności, świeżej żywności, i przemysłowe, w budowlanych zaś grupy te są następujące: projekt, budowa, technika, dekoracja oraz ogród. Należy podkreślić, że przyjęta klasyfikacja równolegle wyznacza podział organizacyjny obszaru handlowego, tzw. strefy. Inaczej określa przyjętą koncepcję organizacji. Strefy dzielą się na podgrupy - działy handlowe. Dalszy podział ma już charakter specjalizacji - czyli klasy i podklasy. Natomiast środki pracy obejmują dwie grupy: zasoby naturalne i narzędzia pracy. Zasoby naturalne to między innymi stosowane paliwa i energia. Narzędzia pracy stanowią bazę techniczną przedsiębiorstwa. Obejmują budynki i budowle oraz ich wyposażenie, czyli urządzenia techniczne. W strukturze obiektów budowlanych najważniejsze miejsce zajmują budowle zamknięte, wspomagane przez strefę parkingową, budowle magazynowe półotwarte i otwarte o nawierzchni twardej. Ogólny plan powierzchni budowli zamkniętej zamieszczono na rysunku 2. 
Rys. 2. Ogólny plan powierzchni budowli na potrzeby systemu logistycznego przedsiębiorstwa handlu detalicznego wielkopowierzchniowego (PHD/W)

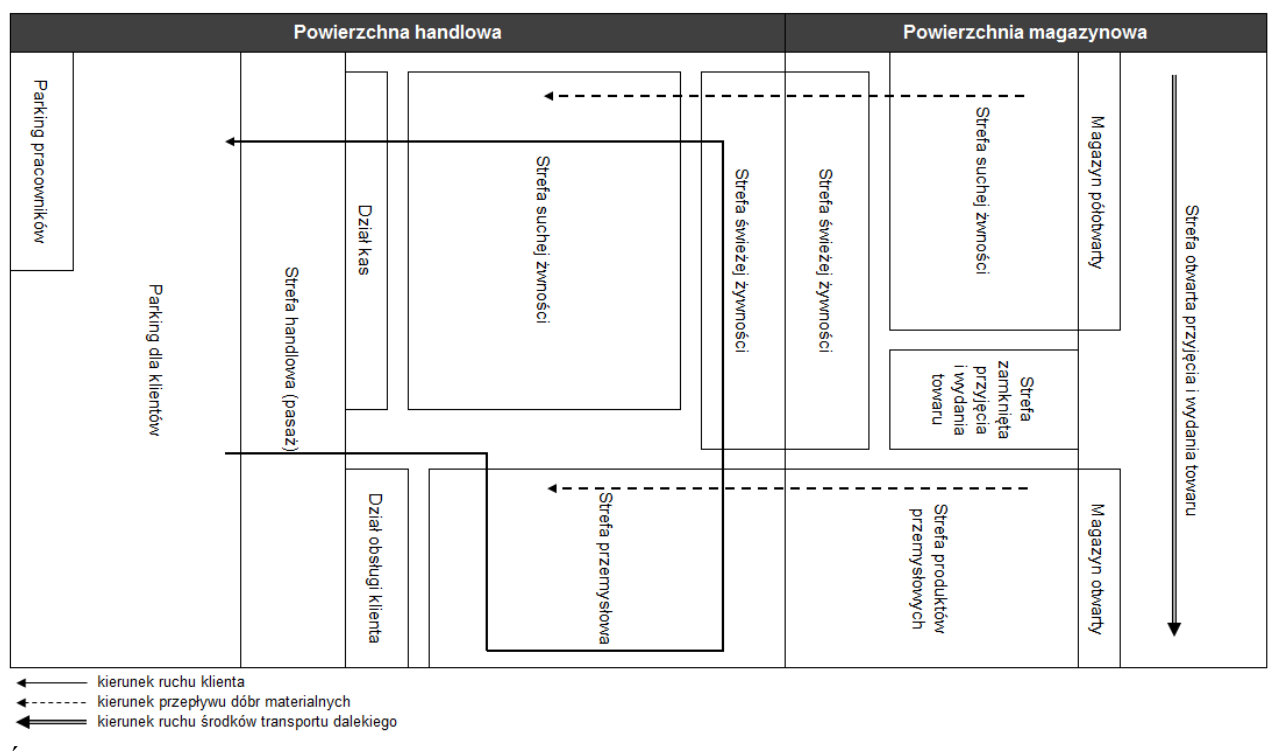

Źródło: opracowanie własne.

Natomiast urządzenia techniczne obejmują cztery podstawowe grupy: urządzenia magazynowe i sklepowe, urządzenia transportowe i manipulacyjne, urządzenia pomocnicze oraz system informatyczny. Należy podkreślić, że stosowane urządzenia mają najczęściej charakter „uniwersalny”, a tym samym pozwalają na obsługę zróżnicowanych towarów. Przypisane są do poszczególnych stref. Ich dobór i ocena użytkowania powinny uwzględniać kryterium efektywności, sprawności, ciągłości i elastyczności pracy. Zakres zastosowania urządzeń technicznych w systemie logistycznym PHD/W przedstawiono na rysunku 3.

Rys. 3. Zakres zastosowania urządzeń technicznych w systemie logistycznym w przedsiębiorstwach handlu detalicznego wielkopowierzchniowego (PHD/W)

\begin{tabular}{|l|l|}
\hline \multicolumn{2}{|c|}{ Urządzenia techniczne } \\
\hline $\begin{array}{l}\text { urządzenia } \\
\text { magazynowe } \\
\text { i sklepowe }\end{array}$ & $\begin{array}{l}\text { do składowania } \\
\text { klimatyzacyjno-wentylacyjne } \\
\text { ochrony przeciwpożarowej } \\
\text { zabezpieczenia } \\
\text { wózki ręczne } \\
\text { wózki unoszące } \\
\text { wózki podnośnikowe }\end{array}$ \\
\hline $\begin{array}{l}\text { urządzenia } \\
\text { transportowe } \\
\text { i manipulacyjne }\end{array}$ \\
\hline urządzenia pomocnicze \\
\hline system informatyczny \\
\hline
\end{tabular}

\begin{tabular}{|c|c|}
\hline \multicolumn{2}{|c|}{ Powierzchnia magazynowa } \\
\hline $\begin{array}{l}\text { strefa przyjęcia } \\
\text { towaru i wydania }\end{array}$ & strefa składowania \\
\hline 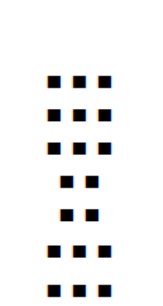 & 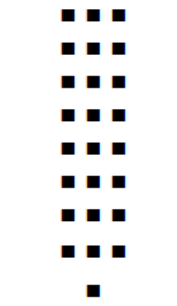 \\
\hline
\end{tabular}

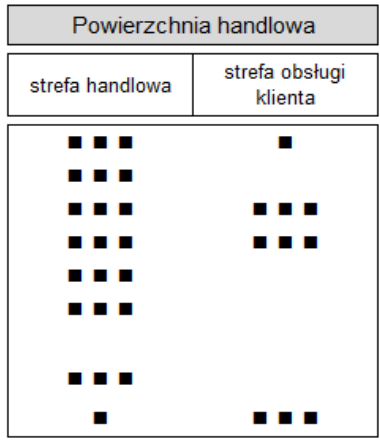

- a powszechnie stosowane

- - stosowane przy realizacji wybranych czynności

- stosowane w organiczonym zakresie

Źródło: opracowanie własne. 
W ujęciu czynnościowym system logistyczny PHD/W definiuje się jako zbiór procesów. Procesy logistyczne mają charakter pomocniczy - wspierają proces główny (sprzedaży), a ich celem jest zapewnienie optymalnego przepływu towarów wraz z informacją. Ich realizacja obejmuje dwie podstawowe fazy: zaopatrzenia i dystrybucji. W ramach obsługi poszczególnych faz podejmowane czynności mogą mieć charakter strategiczny, taktyczny oraz operacyjny. Natomiast pod względem kryterium funkcjonalnego procesy te mogą dotyczyć transportu, magazynowania, obsługi zapasów i opakowań oraz logistycznej obsługę klienta. Strukturę procesów logistycznych w badanym systemie zaprezentowano na rysunku 4.

Rys. 4. Struktura procesów logistycznych w systemie logistycznym przedsiębiorstw handlu detalicznego wielkopowierzchniowego (PHD/W)

\begin{tabular}{|c|c|c|c|c|c|}
\hline \multirow{2}{*}{ Funkcja } & \multirow{2}{*}{$\begin{array}{c}\text { Poziom } \\
\text { zarządzania }\end{array}$} & \multicolumn{4}{|c|}{ Faza } \\
\hline & & zaop & & dyst & \\
\hline transportowy & $\begin{array}{l}\text { stategıczny } \\
\text { taktyczny } \\
\text { operacyjny }\end{array}$ & przygotowanie & realizacja & składowanie & sprzedaż \\
\hline magazynowania & $\begin{array}{l}\text { stategiczny } \\
\text { taktyczny } \\
\text { operacyjny }\end{array}$ & przygotowanie & realizacja & składowanie & sprzedaż \\
\hline obsługi zapasów & $\begin{array}{l}\text { stategiczny } \\
\text { taktyczny } \\
\text { operacyjny }\end{array}$ & przygotowanie & realizacja & składowanie & sprzedaż \\
\hline obsługi opakowań & $\begin{array}{l}\text { stategiczny } \\
\text { taktyczny } \\
\text { operacyjny }\end{array}$ & przygotowanie & realizacja & składowanie & sprzedaż \\
\hline $\begin{array}{l}\text { logistyczna obsługi } \\
\text { klientów }\end{array}$ & $\begin{array}{l}\text { stategiczny } \\
\text { taktyczny } \\
\text { operacyjny }\end{array}$ & przygotowanie & realizacja & składowanie & sprzedaż \\
\hline
\end{tabular}

Źródło: opracowanie własne.

\section{PROCES ZAOPATRZENIA - FAZA PRZYGOTOWANIA}

W literaturze przedmiotu realizacja procesu zaopatrzenia obejmuje dwie podstawowe fazy: przygotowywania oraz realizacji ${ }^{5}$. Uwzględniając strukturę podmiotową, rzeczową i czynnościową systemu logistycznego PHD/W, w ramach pierwszej fazy należy wskazać następujące etapy:

1. opracowanie i przyjęcie polityki zaopatrzeniowej;

2. identyfikacja i charakterystyka potrzeb zaopatrzeniowych;

3. ocena i wybór dostawcy.

W związku z tym punktem wyjścia podejmowanych działań jest opracowanie i przyjęcie polityki zaopatrzeniowej. Jest to dokument strategiczny, który określa cele, normy i reguły postępowania odnoszące się do produktów, kontraktów, komunikacji czy zakupu ${ }^{6}$.

Drugi etap prowadzi do ustalenia wielkości i struktury zamawianych dóbr oraz warunków realizacji dostawy. Należy podkreślić, że przedmiotem zakupu w badanym systemie są zarówno towary, jak i materiały pomocnicze, paliwa stałe i płynne czy fakturowane opakowania. Rozpoznanie wielkości i struktury potrzeb odbywa się poprzez analizę za-

\footnotetext{
${ }^{5}$ K. Ficoń, Logistyka ekonomiczna - procesy logistyczne, Bel Studio, Warszawa 2008.

${ }^{6}$ J. Baran i in., Logistyka - wybrane zagadnienia, Wydawnictwo SGGW, Warszawa 2008.
} 
równo stanu obecnego, jak i konkurencji czy oferty dostawcy. Istotną rolę odgrywają również akcje sprzedażowe i marketingowe oraz przyczyny tworzenia zapasów, czyli bezpieczeństwo, spekulacja czy sezonowość.

Zakres przyjętych działań na etapie trzecim będzie uzależniony od decyzji, czy utrzymuje się współpracę ze znanym dostawcą czy poszukuje nowych. Pod względem specyfiki badanego systemu zakupy mogą mieć charakter zarówno scentralizowany (odbywają się na poziomie całej sieci handlowej), jak i zdecentralizowany (w ramach danej jednostki handlowej). Mogą być realizowane bezpośrednio u producentów oraz pośrednio u dystrybutorów, a dostawy mogą odbywać się bezpośrednio na halę sprzedaży, z utrzymaniem zapasów na magazynie oraz na indywidualne zamówienie klienta. Najczęściej współpraca $\mathrm{z}$ dostawcami oparta jest na stałych umowach, których warunki są renegocjowane raz do roku. Powszechnie do oceny dostawców stosuje się następujące kryteria: czas realizacji zamówienia, niezawodność, gotowość, elastyczność oraz efektywność ${ }^{7}$. Dodatkowo w badanym systemie należy uwzględnić oferowaną cenę i jakość produktów. Schemat fazy przygotowania procesu zaopatrzenia w badanym systemie zamieszczono w tabeli 1 .

Tabela 1. Schemat procesu zaopatrzenia w systemie logistycznym przedsiębiorstw handlu detalicznego wielkopowierzchniowego (PHD/W) - faza przygotowania

\begin{tabular}{|c|c|c|c|c|c|}
\hline Etap & $\begin{array}{l}\text { Dokument } \\
\text { wejścia }\end{array}$ & Zadanie & $\begin{array}{l}\text { Dokument } \\
\text { wyjścia }\end{array}$ & $\begin{array}{l}\text { Kierow- } \\
\text { nik }\end{array}$ & $\begin{array}{l}\text { Wyko- } \\
\text { nawca }\end{array}$ \\
\hline I & & $\begin{array}{l}\text { Opracowanie i przyjęcie polityki } \\
\text { zaopatrzeniowej }\end{array}$ & $\begin{array}{l}\text { Polityka zaopa- } \\
\text { trzeniowa }\end{array}$ & $\begin{array}{l}\text { Dyrektor } \\
\text { sklepu }\end{array}$ & $\begin{array}{l}\text { Dyrektor } \\
\text { DH }\end{array}$ \\
\hline \multirow[t]{2}{*}{ II } & \multirow{3}{*}{$\begin{array}{l}\text { Polityka zaopa- } \\
\text { trzeniowa }\end{array}$} & $\begin{array}{l}\text { Wyznaczenia wielkości i struk- } \\
\text { tury zamawianych dóbr mate- } \\
\text { rialnych }\end{array}$ & & \multirow{7}{*}{$\begin{array}{l}\text { Dyrektor } \\
\text { DH }\end{array}$} & \multirow{7}{*}{$\begin{array}{l}\text { Kierow- } \\
\text { nik DH } \\
\text { Asystent } \\
\text { DH }\end{array}$} \\
\hline & & $\begin{array}{l}\text { Określenie warunków realizacji } \\
\text { dostaw }\end{array}$ & & & \\
\hline \multirow{5}{*}{ II } & & $\begin{array}{l}\text { Wyznaczenie kryteriów zakupu, } \\
\text { ich charakterystyka oraz okre- } \\
\text { ślenie ich istotności }\end{array}$ & $\begin{array}{l}\text { Kryteria oceny } \\
\text { dostawców }\end{array}$ & & \\
\hline & $\begin{array}{l}\text { Kryteria oceny } \\
\text { dostawców }\end{array}$ & $\begin{array}{l}\text { Identyfikacja dostawców, opra- } \\
\text { cowanie bazy danych potencjal- } \\
\text { nych dostawców }\end{array}$ & $\begin{array}{l}\text { Kartoteki do- } \\
\text { stawców }\end{array}$ & & \\
\hline & $\begin{array}{l}\text { Kryteria oceny } \\
\text { dostawców } \\
\text { Kartoteki } \\
\text { dostawców }\end{array}$ & Wysłanie zapytań ofertowych & $\begin{array}{l}\text { Zapytania } \\
\text { ofertowe }\end{array}$ & & \\
\hline & $\begin{array}{l}\text { Oferta } \\
\text { dostawców } \\
\text { Cennik (kata- } \\
\text { log) dostawcy }\end{array}$ & $\begin{array}{l}\text { Analiza i ocena ofert przesła- } \\
\text { nych przez potencjalnych do- } \\
\text { stawców, negocjacja warunków }\end{array}$ & $\begin{array}{l}\text { Karta oceny } \\
\text { dostawców }\end{array}$ & & \\
\hline & $\begin{array}{l}\text { Karta oceny } \\
\text { dostawców }\end{array}$ & $\begin{array}{l}\text { Wybór dostawcy i podpisanie } \\
\text { umowy o wspótpracę }\end{array}$ & $\begin{array}{l}\text { Umowao } \\
\text { wspótpracez z } \\
\text { dostawcami }\end{array}$ & & \\
\hline
\end{tabular}

$\mathrm{DH}$ - dział handlowy

Źródło: opracowanie własne.

${ }^{7}$ J. Twaróg, Mierniki i wskaźniki w logistyce, Instytut Logistyki i Magazynowania, Poznań 2006. 


\section{PROCES ZAOPATRZENIA - FAZA REALIZACJI}

W systemie logistycznym PHD/W druga faza procesu zaopatrzenia - realizacja obejmuje następujące etapy:

1. przygotowanie i wysłanie zamówienia;

2. kontrola realizacji zamówien;

3. przyjęcie towaru w magazynie;

4. rozliczenie dostawy.

W ramach realizacji pierwszego etapu należy wskazać dwa podstawowe zadania: przygotowanie zamówienia oraz jego wysłanie do dostawcy. W badanym systemie zamówienia można podzielić na dwie grupy - jednorazowe oraz stałe. Zamówienia jednorazowe są przygotowywane $\mathrm{w}$ chwili wystąpienia potrzeby, mają charakter jednorazowy i niepowtarzalny lub w ograniczonym stopniu powtarzalny. Natomiast zamówienia stałe, tzw. bieżące, mają charakter ciągły i powtarzalny, dotyczą stałego asortymentu. Przedsiębiorstwo ma doświadczenie $\mathrm{w}$ pracy $\mathrm{z}$ towarem oraz utrzymuje jego zapas. Zamówienia stałe mogą być przygotowywane w warunkach pewności oraz niepewności co do czasu realizacji dostawy czy wielkości sprzedaży poszczególnych pozycji asortymentowych. Zamówienia są wysyłane do dostawców zarówno metodami tradycyjnymi (e-mail, faks) oraz przekazywane bezpośrednio przedstawicielowi handlowemu danej firmy, jak i metodami nowoczesnymi, w tym za pomocą elektronicznej wymiany danych czy strony internetowej.

Etap przygotowania i wysłania zamówienia w systemie logistycznym PHD/W nie kończy procesu zaopatrzenia, a tym samym nie zwalnia $z$ odpowiedzialności działów handlowych za realizację zamówienia. Należy podkreślić, że dostawy do jednostki handlowej odbywają się transportem samochodowym o różnej ładowności i technologii przewozu. Najczęściej organizacją procesu transportowego zajmuje się dostawca. Natomiast podejmowane czynności kontrolne w ramach systemu logistycznego PHD/W obejmują:

- na etapie przygotowania i wysłania zamówienia - potwierdzenie u dostawcy dostępności w czasie i ilości danego towaru; zmiana warunków realizacji dostawy - upusty cenowe czy ilościowe; potwierdzenie otrzymania zamówienia przez dostawcę;

- na etapie realizacji dostawy - potwierdzenie terminowości, ilości i struktury asortymentowej otrzymania dostawy; awizacja dostawy przez dostawcę;

Kolejnym etapem procesu zaopatrzenia jest przyjęcie towaru w magazynie. W systemie logistycznym PHD/W można rozróżnić dwa rodzaje przyjęcia: zewnętrzne, od zewnętrznego dostawcy, oraz wewnętrzne, z magazynu centralnego. Zakres i metody przeprowadzenia kontroli są różne, są one dostosowane do danego produktu czy dostawcy i uwzględniają wewnętrznych możliwości. Przeprowadzona kontrola może mieć charakter ilościowy, co pozwala na wykrycie uszkodzeń, pomyłek rodzajowych i ilościowych, oraz jakościowa, za pomocą metody organoleptycznej czy zgodności cech materiałów z obowiązującymi normami branżowymi.

Ostatnim etapem procesu zaopatrzenia jest rozliczenie dostawy. W ramach tego etapu można wskazać dwa zadania. W wypadku wystąpienia niezgodności w dostawie zgłasza się reklamację do dostawców. Natomiast jeśli nie ma żadnych uwag co do realizacji dostawy zatwierdza się dostawę i rozlicza się ją. Podsumowując, schemat fazy realizacji procesu zaopatrzenia w badanym systemie zamieszczono w tabeli 2 . 
Tabela 2. Schemat procesu zaopatrzenia w systemie logistycznym przedsiębiorstw handlu detalicznego wielkopowierzchniowego (PHD/W) - faza realizacji

\begin{tabular}{|c|c|c|c|c|c|}
\hline Etap & $\begin{array}{l}\text { Dokument } \\
\text { wejścia }\end{array}$ & Zadanie & $\begin{array}{l}\text { Dokument } \\
\text { wyjścia }\end{array}$ & Kierownik & $\begin{array}{l}\text { Wyko- } \\
\text { nawca }\end{array}$ \\
\hline I & $\begin{array}{l}\text { Kartoteki } \\
\text { dostawców } \\
\text { Harmonogram } \\
\text { dostaw }\end{array}$ & $\begin{array}{l}\text { Przygotowanie zamówienia i } \\
\text { jego wysłanie do dostawcy }\end{array}$ & Zamówienie & \multirow[t]{2}{*}{$\begin{array}{l}\text { Dyrektor } \\
\text { DH }\end{array}$} & \multirow{2}{*}{$\begin{array}{l}\text { Kierownik } \\
\text { DH } \\
\text { Asystent } \\
\text { DH }\end{array}$} \\
\hline II & $\begin{array}{l}\text { Potwierdzenie } \\
\text { zamówienia }\end{array}$ & Kontrola realizacji zamówienia & $\begin{array}{l}\text { Awizacja do- } \\
\text { stawy }\end{array}$ & & \\
\hline \multirow{6}{*}{ III } & $\begin{array}{l}\text { Dokumenty } \\
\text { przewozowe }\end{array}$ & $\begin{array}{l}\text { Sprawdzenie zgodności dostawy } \\
\text { z zamówieniem i dokumentami } \\
\text { przewozowymi }\end{array}$ & & \multirow{6}{*}{$\begin{array}{l}\text { Kierownik } \\
\text { DPW }\end{array}$} & \multirow{6}{*}{$\begin{array}{l}\text { Asystent } \\
\text { DPW } \\
\text { Pracownik } \\
\text { DPW }\end{array}$} \\
\hline & $\begin{array}{l}\text { Karta kontroli } \\
\text { środka trans- } \\
\text { portu }\end{array}$ & $\begin{array}{l}\text { Kontrola środka transportu i } \\
\text { weryfikacja stanu zamawianego } \\
\text { towaru }\end{array}$ & & & \\
\hline & & $\begin{array}{l}\text { Rozładunek dostawy ze środka } \\
\text { transportu z zastosowaniem } \\
\text { posiadanych środków pracy }\end{array}$ & & & \\
\hline & $\begin{array}{l}\text { Dokumenty } \\
\text { przewozowe }\end{array}$ & $\begin{array}{l}\text { Sortowanie towaru, identyfika- } \\
\text { cja, kontrola ilościowa i jako- } \\
\text { ściowa, w przypadku stwierdze- } \\
\text { nia nieprawidłowości podjęcie } \\
\text { działań korygujących }\end{array}$ & $\begin{array}{l}\text { Protokót } \\
\text { stwierdzenia } \\
\text { nieprawidtowo- } \\
\text { ści }\end{array}$ & & \\
\hline & & Potwierdzenie dostawy & & & \\
\hline & & $\begin{array}{l}\text { Przygotowanie towarów do } \\
\text { składowania i przekazanie } \\
\text { dostawy }\end{array}$ & & & \\
\hline \multirow[t]{2}{*}{ IV } & & $\begin{array}{l}\text { Zgłoszenie reklamacji i jej } \\
\text { obsługa }\end{array}$ & $\begin{array}{l}\text { Protokół rekla- } \\
\text { macji } \\
\text { Protokót zawro- } \\
\text { tu }\end{array}$ & $\begin{array}{l}\text { Kierownik } \\
\text { DH }\end{array}$ & $\begin{array}{l}\text { Asystent } \\
\text { DH }\end{array}$ \\
\hline & & Rozliczenie dostawy & & $\begin{array}{l}\text { Dyrektor } \\
\text { DH }\end{array}$ & $\begin{array}{l}\text { Kierownik } \\
\text { DH }\end{array}$ \\
\hline
\end{tabular}

DH - dział handlowy; DPW - dział przyjęcia i wydania towaru

Źródło: opracowanie własne.

\section{PODSUMOWANIE}

Podstawowym zadaniem działów handlowych w PHD/W jest sprzedaż. Proces sprzedaży dzieli się w układzie poziomym na poszczególne podprocesy, co odzwierciedla strukturę organizacyjną działów. Zakres obowiązków (samodzielności) osób odpowiedzialnych za dział handlowy jest różny i zależy od przyjętej formy organizacyjnej sieci. Podział ten pozwala na specjalizację w zakresie obsługi i zarządzania daną grupą asortymentową. Natomiast logistyka pełni funkcję pomocniczą, wspomaga przepływ dóbr materialnych między rynkiem zaopatrzeniowym a klientem ostatecznym. Proces zaopatrzenia jest jednym z istotnych realizowanych tam procesów logistycznych. Od jego efektywności, sprawności, elastyczności czy ciągłości zależy wynik finansowy przedsiębiorstwa. Należy podkreślić, że realizacji poszczególnych zadań zaopatrzeniowych towarzyszy duża niepewność. Bardzo duża liczba produktów znajduje się w dyspozycji jednego działu handlowego. Pod względem kryterium szerokości czy głębokości asortymentu obsługiwa- 
ne produkty charakteryzują się dużym zróżnicowaniem. Niekiedy ten sam produkt dostarczany jest przez różnych dostawców, a podstawowym kryterium wyboru staje się cena czy czas realizacji zamówienia. Ponadto występuje bardzo duża liczba dostawców przypisana do danego działu handlowego, zarówno o zasięgu krajowym, jak i lokalnym, a tym samym odnotowuje się znaczne zróżnicowanie warunków zakupu. Natomiast obrót na poszczególnych pozycjach jest różny, występują produkty charakteryzujące się stałą, pewną sprzedażą, jak i dużą niepewnością, uzależnioną od uwarunkowania otoczenia. Dlatego istotną rolę odgrywają wiedza, umiejętności i kompetencje osób odpowiedzialnych za dany dział handlowy, przejrzyste i jednoznaczne obowiązujące procedury postępowania oraz wybór sprawdzonych, pewnych i konkurencyjnych dostawców, których oferta handlowa i warunki realizacji dostaw odzwierciedla potrzeby klientów.

\section{LITERATURA}

[1] Armstrong J.G., Kotler Ph., Marketing - Wprowadzenie, Oficyna Wydawnicza Wolters Kluwer business, Warszaw 2012.

[2] Baran J. i in., Logistyka - wybrane zagadnienia, Wydawnictwo SGGW, Warszawa 2008.

[3] Brzeziński M., Logistyka w przedsiębiorstwie, Dom Wydawniczy Bellona, Warszawa 2006.

[4] Christopher M., Strategia zarzadzania dystrybucja, Agencja Wydawnicza Placet, Warszawa 1996.

[5] Czubała A., Dystrybucja produktów, Polskie Wydawnictwo Ekonomiczne, Warszawa 2001.

[6] Dwiliński L., Zarysy logistyki przedsiębiorstwa, Oficyna Wydawnicza Politechniki Warszawskiej, Warszawa 2006.

[7] Ficoń K., Logistyka ekonomiczna - procesy logistyczne, Bel Studio, Warszawa 2008.

[8] Kompendium wiedzy o logistyce, red. E. Gołembska, Wydawnictwo Naukowe PWN, Warszawa-Poznań 2001.

[9] Logistyka, red. D. Kisperska-Moroń, S. Krzyżaniak, Biblioteka Logistyka, Poznań 2009.

[10] Logistyka dystrybucji, red. K. Rutkowski, Difin, Warszawa 2000.

[11] Twaróg J., Mierniki $i$ wskaźniki w logistyce, Instytut Logistyki i Magazynowania, Poznań 2006.

\section{IDENTIFICATION OF SUPPLY PROCESS IN THE LOGISTIC SYSTEM OF LARGE-AREA RETAIL ENTERPRISES}

An analysis of the literature shows a lack of detailed studies relating to the concept and structure of the logistics system of large-area retail enterprises and characteristics of the performed processes there. Presented content is of a general nature, it does not take into account the specifics of entities or the subject of the sector. The aim of this article is to supplement the resulting gap. The actions taken lead to the identification and characterization of a supply process in the logistic system of a large-area retail enterprises through defining a purpose and stages, used documents, persons responsible for it and contractors. The applied method of research is a literature review and direct observation. Realization of it take place in two stages. The first stage includes identification and characterization of the logistics system by the enterprise in terms of the subject, tangible and functional. The result of undertaken activities is to determine and discuss the organizational structure of the audited company and develop a plan for development of the main area, i.e. the market hall and warehouse. In addition, as a part of this stage, characterization of the means work are included by identification of the handling object and used technical equipment. In the final part the main logistics processes are indicated. The second stage includes identification and characterization of the procurement process in the 
studied system. Including the commonly used division of the procurement process into two phases, i.e. the preparation phase and implementation phase and subject, tangible, and functional structure of a logistics system, within each of the phases have been designated stages and tasks. Whereas, in frame of particular tasks responsible persons for it is implementation, constructors and used documents have been identified. Construction and development of scheme of the supply process is a final result of considerations.

Keywords: logistics, distribution, supply, demand52, supplier, supply

\section{DOI: 10.7862/rz.2016.mmr.15}

Tekst złożono w redakcji: sierpień 2016

Przyjęto do druku: wrzesień 2016 